\title{
IAMJ
}

INTERNATIONAL

AYURVEDIC

MEDICAL JOURNAL

Review Article

ISSN: 23205091

미요 (1)

Impact Factor: 5.34

\section{MANAGEMENT OF CHRONIC KIDNEY DISEASE BY AYURVEDA W.S.R. TO BASTI}

\author{
Bhuvnesh Sharma ${ }^{1}$, Gyanendra Datta Shukla ${ }^{2}$ Parul Sharma $^{3}$ \\ ${ }^{1}$ MD Scholar, ${ }^{2}$ Associate Professor, ${ }^{3}$ Assistant Professor, Department of Panchakarma Rishikul Campus, \\ Uttarakhand Ayurveda University, Haridwar, Uttarakhand, India
}

Corresponding Author: ayurveda.nature@gmail.com

https://doi.org/10.46607/iamj2008092020

(Published online: September 2020)

Open Access

(C) International Ayurvedic Medical Journal, India 2020

Article Received: 03/08/2020 - Peer Reviewed: 30/08/2020 - Accepted for Publication: 02/09/2020

Check for updates

\begin{abstract}
Kidneys plays a vital role in homeostasis by maintaining the body fluid and removing the harmful toxins out of the body through urine formation. Chronic kidney disease is a type of kidney disease which is progressive in nature and there is gradual loss of kidney function over a period of months or years and have complex and different etiopathologies. With the growing number of cases and keeping in mind the available conventional line of treatment and its financial burden on patient, Ayurveda through its holistic line of management, either in the form of Shamana \& Shodhana or in the form of dietary advices stand distinct and it seems to be effective and safe. And by including proper daily dietary rules and regimens in patients of Chronic kidney disease (CKD) it can be very effectively managed. Here Trinpanchmool, Punarnava, Gokshur used in Basti. Basti plays a vital role here in CKD, it helps in expelling out the uremic toxins which originates in gut thereby improving the quality of life and reducing the sign and symptoms of disease.
\end{abstract}

Keywords: Chronic kidney disease, Uremia, Shodhana, Shamana, Punarnava

\section{INTRODUCTION}

Chronic kidney disease is myriad of various pathophysiological mechanisms that is taking place in our body because of which there is gradual loss of kidney functions over the period of time. Although diabetes and hypertension are the leading cause, numerous other causes are there which leads to deterioration of kidney function. The Global Burden Disease 2015 study also estimated that, in 2015, 1.2 million people died from 
kidney failure, an increase of $32 \%$ since $2005 .{ }^{1}$ In 2010 , an estimated 2.3-7.1 million people with end-stage kidney disease died without access to chronic dialysis. $^{2}$ Additionally, each year, around 1.7 million people are thought to die from acute kidney injury. ${ }^{3}$ Overall, therefore, an estimated 5-10 million people die annually from kidney disease. Kidney disease is associated with a tremendous economic burden. High-income countries typically spend more than $2-3 \%$ of their annual health-care budget on the treatment of end-stage kidney disease, even though those receiving such treatment represent under $0.03 \%$ of the total population. ${ }^{4}$ In 2010, 2.62 million people received dialysis worldwide and the need for dialysis was projected to double by 2030. ${ }^{5}$ Chronic kidney disease progression associated with serious complications like cardiovascular disease, anaemia, metabolic bone disease. Assessment of CKD patient is done for presence of these complications and accordingly line of treatment is decided. Number of CKD patient is on rise due to growing number of cases of Diabetes and hypertension, and considering global burden of disease, a multidisciplinary treatment approach is required.

\section{CKD classification/ staging}

$\mathrm{CKD}$ is defined as the presence of kidney damage, manifested by abnormal albumin excretion of diseased kidney function, quantified by measured or estimated glomerular filtration rate (GFR), that persist for more than three months. ${ }^{6,7}$ To facilitate assessment of CKD severity, the National kidney foundation developed criteria, as part of its Kidney Disease Outcomes Quality Initiative (NKF DOQI ${ }^{\mathrm{TM}}$ ), stratify CKD patients. ${ }^{8}$

- $\quad$ Stage 1: normal eGFR $\geq 90 \mathrm{~mL} / \mathrm{min}$ per $1.73 \mathrm{~m} 2$ and persistent albuminuria

- $\quad$ Stage 2: eGFR between 60 to $89 \mathrm{~mL} / \mathrm{min}$ per 1.73 $\mathrm{m} 2$

- Stage 3: eGFR between 30 to $59 \mathrm{~mL} / \mathrm{min}$ per 1.73 $\mathrm{m} 2$

- Stage 4: eGFR between 15 to $29 \mathrm{~mL} / \mathrm{min}$ per 1.73 $\mathrm{m} 2$

- Stage 5: eGFR of $<15 \mathrm{~mL} / \mathrm{min}$ per $1.73 \mathrm{~m} 2$ or endstage renal disease

\section{Ayurvedic Review}

Chronic kidney disease (CKD) is not clearly mentioned in Ayurveda classical texts, but dispersed fragment of disease can be traced in various chapters, under different heading. While mentioning the genesis of Vrukka (kidney) Sushrut in Sharir Sthan told that it is a Matruj Avayava and it is formed of Rakta and Meda Dhatus. ${ }^{9}$ In Ayurveda CKD, can be considered as a Mootra Dosh Vikar which causes oedema. Both Kidney are root of Medovaha Srotas. ${ }^{10}$ According to Acharya Charak the causes of Mootra dosha vikar are intake of drinks and food, sexual intercourse while having the urge for micturition, and suppression of the urge of micturition, disorders of wasting or malnutrition and severe traumatic injury. ${ }^{11}$ The pathogenesis of kidney disease is not separately mentioned. It can be included in Prameha, $\mathrm{Mu}$ tra dosha, Mutra krichchra, injury of Vankshana, Ashmari (renal stones) and oedema (Shofa) etc. Chronic kidney disease is a very complex Vyadhi Sankara. Depending upon causative factors stage etc. it shows different signs and symptoms. Etiological factors of CKD ranges between Roopavasthaa, upadrava and Vyadhisankara of following diseases:

Paandu; Shotha; Parmeha Upadrava; Udaavarta; Ashmaree Upadrava, Kshatksheen; Vaatvyadhi; Mutrakrichchra; Upadrava

Most of sign and symptoms present in CKD matched with signs and symptoms of Rasapradoshaj Vyaadhi. Sign and symptoms of Rasapradoshaj Vyaadhi are loss of desire of food, anorexia, distaste in mouth, loss of taste sensation, nausea, heaviness, drowsiness, body ache, fever, feeling of darkness, paleness, obstruction in channels, impotency, malaise, leanness, loss of digestive power, untimely wrinkles and grey hairs. ${ }^{12}$ In Charak Samhita it is said that Kidney and bladder are the root of the channels carrying urine and fat, the opening of these channels get affected by Meda, Mansa and Jala Dhatus of the body. The vitiated Doshas while coming in contact with the opening of these channels obstructs them. This result in the manifestation of kidney disease. ${ }^{13}$

Approach of Management: Ayurveda offers a comprehensive approach in the treatment of CKD. Abstinence from the causative factor (Nidan Parivarjan) is 
the first and foremost advice given to the patients in Ayurveda. Management of Systemic Derangements (Bheshaja Chikitsa), aims at treating Amotpatti by Jathragni improvement thereby removing Srotorodha. Management in form of Shaman Chikitsa and Shodhan Chikitsa can be done. While explaining the genesis of Kidney (Vrukka) Acharya Sushrut has said that it is formed from Rakta and Meda Dhatu. Ahaara is converted to Rasa Dhatu and it is further converted to Raktadi remaining Dhatus. So, line of treatment should be focusing on Jathargani correction, which in turns gives strength to Dhatwagnis leading to formation of fine quality of Rasadi Dhatus, also the selection of herbal drugs which specifically act on Rakta and Meda Dhatu, leading to formation of Saara Bhaaga of the both the Dhatus leading to proper nourishment of Vrukka (kidney). After Shamana Chikitsa when Laxana of Daurbalya and Dhatu Kshaya is reduced in patient then he can be given Mrudu Virechana and Basti.

Shamana Chikitsa: In Shamana Chikitsa drugs like Trinpanchmool, Gokshur, Punarnava can be used. Trinpanchmool is having Basti Shodhaka property. ${ }^{14}$ Gokshur is Sheet Veerya, Balya, Basti Vishodhaka, Madhur Vipaki, Deepana, Vrushya, Pushtikara and Ashmarihara. Pramehahara, Shvasahara, Kasahara, Arshahara, also useful in Hridroga and Vatahara in nature. ${ }^{15}$ Punarnava is Shophahara in nature. ${ }^{16}$ Gokshur is one among the drug of Mutravirechaniya Gana ${ }^{17}$, and it act as Anulomaka of Apaana Vayu. Punarnava has Ushna Veerya property which corrects Srotosang in Vrukka. It is anti-inflammatory and helps in regeneration of kidney tissues ${ }^{18}$. Study was carried out to find the efficacy of Gokshur Punarnava Basti in the management of microalbuminuria in diabetes mellitus, it is found to be very effective and safe. ${ }^{19}$ As the symptoms of CKD resembles Rasavaha Srotas Dushti. Agniman$d y a$ and Aamotpatti are two closely associated features in the pathogenesis of disease. Trinpancmool, Gokshur and Punarnava not only help in correcting Agnimandya but also removal of morbid Doshas.

Samshodhana Chikitsa: Sanshodhana Chikitsa is helpful in removal of morbid Doshas, it also helps in preventing recurrence and progression of disease. Various Samshodhana Chikitsa like Basti, Mridu Virechan can be given to patient. Before carrying out Sanshodhan Chikitsa Deepana Pachana is done. Basti is the treatment mostly effective on Pakvashaya in which urine formation carried out. ${ }^{20}$ It is not only effective in treating Vaataja Rogas but is also effective in Pittaja, Kaphaja, Sansargaja, Sannipataja and Raktaja Rogas. ${ }^{21}$ Ayurveda emphasizes the importance of Trimarma (Sira, Hrudaya and Basti) which are to be protected, if not it may lead to death. Basti Marma although structurally similar to bladder but here the entire renal functioning is to be considered among which kidneys plays a major and vital role. So, considering Basti Marma is affected in CKD and keeping in mind importance of Marma Paripalana, Basti Karma can be considered as treatment of choice.

\section{DISCUSSION}

In chronic kidney disease, there is gradual loss of nephrons which further proceed to end stage renal disease. So, there is definite involvement of Vaat Dosha which are leading to degenerative changes in kidney. So Basti being the best modality in treatment of Vaat Viakras may play an excellent role here in controlling the further progression of disease. Basti helps in removal of morbid Doshas which thereby helps in achieving equilibrium of Doshas in body. Progression of CKD leads to CRF where uremic toxins start developing and showing effect on body. The researches have shown that uremic toxins originate in gut. Microbes in colon produces compounds, normally excreted by the kidneys, which are potential uremic toxins. ${ }^{22}$ Solutes made by colon microbes may contribute to uremic illness. ${ }^{23,24}$ Such putrefaction products were originally detected in urine and subsequently shown to accumulate in plasma when the kidneys failed. ${ }^{25}$ Probable mode of action of Basti can be understand (1) by absorption mechanism, (2) by system biology concept, (3) by neural stimulation mechanism, (4) by excretory mechanism. Pharmacodynamics outcome of Basti Karma may be due to functioning of the one or combined effect of all the four mechanisms. ${ }^{26}$ Here Trinpanchmool along with Gokshur and Punarnava used in Kwath Dravya and Sneha Dravya for preparation of Niruha. Kidney (Vrukka) is Matruj Avayava and it is Rakta Meda 
Pradhan, so we need drugs which not only helps in Basti Shodhan and Rakta Prasadan but also not Teekshna in nature. Combination of Trinpanchmool Gokshur Punarnava are not only Bastishodhak, but also Sheet Veerya in nature. Punarnava have proven effect of regeneration of tissue. So, this combination of drugs in Niruha Basti preparation can be helpful in patients of CKD to stop its progression. Niruha Basti is hyper osmotic solution which causes movement of solvent from cells of colon to the lumen containing Basti Dravya facilitates the absorption of endotoxin and produce detoxification during elimination. ${ }^{27}$ This is probably how Basti expels toxins from the body and cleanses colon. Intestines being highly innervated, Basti Dravya stimulates the nerve ending of rectum and colon thereby activating autonomic nervous system and thus helps in excretion of vitiated Doshas and Malas.

\section{CONCLUSION}

With the growing number of cases of CKD and keeping in mind the available conventional line of treatment and its financial burden on patient, Ayurveda through its holistic line of management, either in the form of Shaman and Shodhan or in the form of dietary advices stand distinct and it seems to be effective and safe. Basti Chikitsa given with the help of herbal drugs help in improving the quality of life and eliminating the uremic toxins from the body and put a positive impact on body as whole.

\section{REFERENCES}

1. Wang H, Naghavi M, Allen C, Barber RM, Bhutta ZA, Carter A, et al.; GBD 2015 Mortality and Causes of Death Collaborators. Global, regional, and national life expectancy, all-cause mortality, and cause-specific mortality for 249 causes of death, 1980-2015: a systematic analysis for the Global Burden of Disease Study 2015. Lancet. 2016 Oct 8;388(10053):1459544.http://dx.doi.org/10.1016/S0140-6736(16)310121 pmid: 27733281

2. Liyanage $T$, Ninomiya $T$, Jha $V$, Neal B, Patrice HM, Okpechi I, et al. Worldwide access to treatment for endstage kidney disease: a systematic review. Lancet. 2015 May

16;385(9981):1975-
82. http://dx.doi.org/10.1016/S0140-6736(14)616019 pmid: 25777665

3. Mehta RL, Cerdá J, Burdmann EA, Tonelli M, GarcíaGarcía G, Jha V, et al. International Society of Nephrology's 0by 25 initiative for acute kidney injury (zero preventable deaths by 2025): a human rights case for nephrology. Lancet. 2015 Jun 27;385(9987):261643. http://dx.doi.org/10.1016/S0140-6736(15)60126Xpmid: 25777661

4. Couser WG, Remuzzi G, Mendis S, Tonelli M. The contribution of chronic kidney disease to the global burden of major noncommunicable diseases. Kidney Int. 2011 Dec;80(12):125870. http://dx.doi.org/10.1038/ki.2011.368 pmid: 21993 585

5. Liyanage T, Ninomiya T, Jha V, Neal B, Patrice HM, Okpechi I, et al. Worldwide access to treatment for endstage kidney disease: a systematic review. Lancet. 2015 May 16;385(9981):197582. http://dx.doi.org/10.1016/S0140-6736(14)616019 pmid: 25777665

6. KDOQI Clinical Practice Guidelines and Clinical Practice Recommendations for Anemia in Chronic Kidney Disease. Am.J.Kidney Dis 2006;47:S11-S145. [PubMed: 16678659]

7. Levey AS, Eckardt KU, Tsukamoto Y, et al. Definition and classification of chronic kidney disease: a position statement from Kidney Disease: Improving Global Outcomes (KDIGO). Kidney Int 2005;67:2089-2100. [PubMed: 15882252]

8. Coresh J, Astor BC, Greene T, et al. Prevalence of chronic kidney disease and decreased kidney function in the adult US population: Third National Health and Nutrition Examination Survey. American Journal of Kidney Diseases 2003;41:1-12. [PubMed: 12500213]

9. Sushrut Shareer Sthan shloka 3/31.

10. Agnivesha In: Charak, Dridhbala, Charak SamhitaViman Sthan shloka 5/8, ed. Prof. Priyavrat Sharma, Vol 1, $9^{\text {th }}$ edition, Chaukhamba Orientalis; 2005

11. Agnivesha In: Charak, Dridhbala, Charak Samhita Viman Sthan shloka 5/20, ed. Prof. Priyavrat Sharma, Vol. 1, $9^{\text {th }}$ edition, Chaukhamba Orientalis; 2005

12. Agnivesha In: Charak, Dridhbala, Charak Samhita Sutra Sthan shloka28/9-10, ed. Prof. Priyavrat Sharma, Vol. 1, $9^{\text {th }}$ edition, Chaukhamba Orientalis; 2005

13. Agnivesha In: Charak, Dridhbala, Charak Samhita Viman Sthan shloka 5/8, ed. Prof. Priyavrat Sharma, Vol. 1, $9^{\text {th }}$ edition, Chaukhamba Orientalis; 2005 
14. Chakrapanidatta Chakradatta mutrakrichhra chikitsa 32/4, by Jagadishvaraprasad Tripathi,ed. Bhishagratna Pt. Brahmshankara Mishra $5^{\text {th }}$ edition, Varanasi: Chowkhamba Sanskrit Series office; 1983.

15. Bhavaprakash samhita, guduchayadi varga, 43 shloka, ed. Vishwanathdwivedi Sahstri, $9^{\text {th }}$ edition, Motilal Banarasidas, 2007.

16. Sushrut, In: Sushrut Samhita Sutra Sthan Annapanvidhi,46 shloka 255, Kaviraj Ambikadutta Shastri, Chaukhamba Sanskrit series, 2007

17. Agnivesha . In: Charaka, Dridhabala, Charaka Samhita, Sutra Sthana, Shadvirechana Shatashritiya, 4/15. Reprint ed. Jadavaji Trikamji Acharya., editor. Vol. 33. Varanasi: Chaukhamba Krishnadas Academy; 2006.

18. Mishra J, Singh R. The effect of indigenous drug Boerhaavia diffusa on kidney regeneration. Indian J Pharmacol. 1980;12:59-64.

19. Ramteke RS, Thakar AB, Trivedi AH, Patil PD. Clinical efficacy of Gokshura-Punarnava Basti in the management of microalbuminuria in diabetes mellitus. Ayu. 2012;33(4):537-541. doi:10.4103/0974-8520.110535

20. Sushrut In: Sushrut Samhita Nidan Sthan Ashmari Nidan 3 shloka 20-23, Kaviraj Ambikadutta Shastri, Chaukhamba Sanskrit Series, 2007

21. Sushrut In: Sushrut Samhita Chikitsa Sthan Netrabastipramanpravibhag Chikitsitam 35 shloka 6, Kaviraj Ambikadutta Shastri Chaukhamba Sanskrit Series, 2007

22. Pavel A. Aronov et al. Colonic contribution of uremic solutes. JASN September 2011, 22 (9) 17691776; DOI: https://doi.org/10.1681/ASN.2010121220

23. Uremic toxins originating from colonic microbial metabolism. Evenepoel P, Meijers BK, Bammens BR, Verbeke K Kidney Int Suppl. 2009 Dec; (114):S129.[PubMed] [Ref list]

24. The gut: the forgotten organ in uremia? Schepers $E$, Glorieux G, Vanholder R Blood Purif. 2010; 29(2):1306.[PubMed] [Ref list]

25. Schreiner G, Maher J: Biochemistry of uremia. In: Uremia, Springfield, MA, Charles Thomas, 1960, pp 5585 [Google Scholar] [Ref list]

26. Gyanendra D. Shukla, Shweta Pandey, Anup B. Thakar. Pharmacodynamic understanding of Basti: A contemporary approach; International Journal of pharmaceutical \& Biological Archives 2012; 3(4): 893-896

27. Ibidem 11 page. $231-237$

\section{Source of Support: Nil \\ Conflict of Interest: None Declared}

How to cite this URL: Bhuvnesh Sharma et al: Management Of Chronic Kidney Disease By Ayurveda w.s.r. To Basti. International Ayurvedic Medical Journal \{online\} 2020 \{cited September, 2020 $\quad$ Available from: http://www.iamj.in/posts/images/upload/4426 4430.pdf 